\title{
Risk Relievers in Mail-Order Catalogue Retailing: The Case of the High-Frequency Purchaser of Low-Involvement Products
}

\author{
N S Terblanché \\ Department of Business Management, University of Stellenbosch \\ C Boshoff \\ Department of Business Management, University of Port Elizabeth \\ E v d M Smit \\ Graduate School of Business, University of Stellenbosch
}

\begin{abstract}
This article reports on the identification of how various risk relievers, available to consumers and mail-order catalogue organisations, influence general risk perception. Consumers who have purchased low-involvement products on a number of occasions by mail-order constitute the sample. The findings are that two of the major risk relievers significantly reduce, whilst another one increases, the general risk perceptions of mail-order customers when buying lowinvolvement goods. These findings are important to mail-order catalogue managers because they confirm that a variety of risk relievers need to be offered to ensure that perceived risks are properly addressed.
\end{abstract}

JEL M 31

\section{INTRODUCTION}

Three reasons are put forward as to why shops traditionally served as primary distributors of retail products (Rosenberg \& Hirschman, 1980), namely :

- $\quad$ customers were accustomed to purchasing at shops;

- few acceptable alternatives existed and

- the value of consumers' money exceeded the value of the time used for shopping.

Retailers overcome a number of discrepancies for consumers. Typical of these are time, spatial, assortment and information gaps. Recent years have however witnessed a large increase in the volume of retailing transactions done at 
shopping formats other than the conventional retail shops that overcome the above-mentioned discrepancies. The past two decades there has been an increase in the use of multiple channels for the distribution of products by manufacturers and intermediaries. McNair and May (1978) mention the role of technology in this context and argue that new forms and applications of technology make mailcatalogue buying an acceptable shopping format for an increasing number of consumers.

Various previous studies have found that in-shop shopping is perceived as having less risks than non-shop or in-home shopping (Spence, Engel and Blackwell, 1970; Festervand, Snyder and Tsalikis, 1986; Hawes \& Lumpkin, 1986; McCorkle, 1990). A risk reliever can be defined as a device or action that is initiated by a buyer or a seller, which is used to carry out a risk reduction strategy. A number of risk relievers such as information seeking, store image and major brand image that are freely available to in-shop consumers, are however not available to mail-catalogue consumers. A consumer might use a specific risk reliever as a way to get a higher probability of purchase success or rely on another as a means of minimising the loss incurred in case of product failure. This article deals with how consumers who have purchased lowinvolvement products, perceive various risk relievers available to them.

\section{OBJECTIVES}

The primary objective of this study was to identify which risk relievers, that are available to consumers and mail-catalogue organisations, actually reduce observed general risk perceptions of consumers who have purchased lowinvolvement products in the past by mail-order. Insight into the impact of such risk relievers is useful to the design of product offerings and mail-order catalogue design and should, hopefully, enhance the sales volumes of direct marketers who can convert these findings into a lower risk associated with buying a product by mail-order.

\section{THEORETICAL CONSIDERATIONS}

Before discussing the risk relievers that are available to consumers and mailcatalogue organisations, it is necessary to consider the market in which mailcatalogue marketing takes place. 


\section{The market for mail-catalogues}

Rapp and Collins (1990) identified the following trends in and characteristics of the marketplace that favour direct-order retailing : target markets that change continually because of changing demographics and lifestyles; demands on personal time; overcrowding by too many new products, services and stores; weakening of the impact of television advertising; decline in brand and store loyalty; and clutter, overkill and waste of advertising. The net effect of these trends is that it has become increasingly difficult to capture and keep the attention of the consumer. One way in which retailers succeed in achieving this, is to contact the consumer directly.

Shopping in retail outlets will undoubtedly remain a vital social as well as a functional activity for a long time to come. There are, however, certain social and economic forces that make shopping at home attractive. Some of these forces are: the annoyance and wastefulness of having to contend with traffic and shopping crowds; the widely noted deterioration in the quality of service in many retail shops; an increase in the number of career and professional women; a greater emphasis on standardisation and branding of products (which reduces the risk involved in shopping at home); and the growing use of credit cards (Rapp \& Collins, 1990; Darian, 1987). The value of the consumer's time has also increased tremendously over the past decade and any means that can give a consumer more shopping time flexibility is viewed as positive by consumers. Direct mail-order retailing thus offers consumers flexible shopping hours. Rosenberg and Hirschman (1980) also identified the willingness of consumers to change, and their acceptance of technology used to market products directly, as further reasons that will make shopping in the home attractive.

\section{Risk relievers in mail-order catalogue retailing}

Various perceived risks are attached to mail-order catalogue retailing, and the consumer selects whichever risk reliever appears best suited to the type of risk that is involved.

Akaah and Korgaonkar (1988) undertook a conjoint analysis to investigate consumer preferences for risk relievers in direct order retailing. They found that a money-back guarantee ranked as the most important risk reliever. This was followed by the name of the manufacturer, the cost of the product, the reputation of the distributor, free sample/trial, endorsement by a trusted person, experience of the brand and the novelty of the product, respectively. It was also found that the lower the relative cost of an offering is, the greater will be the incentive to shop for it by means of direct-order retailing. It was reported by Hawes and Lumpkin (1986) that price/quality perception, personal experience, as well as 
money-back guarantees are the most important risk reduction techniques used by in-home shopping respondents. Festervand, Snyder and Tsalikis (1986) and Jasper and Ouelette (1994) found that catalogue buyers with prior satisfactory purchase experience, perceived significantly less risk than catalogue buyers with prior unsatisfactory purchasing experience.

The risk relievers available to consumers in direct order retailing are (Roselius, 1971; Hoover, Green and Saegert, 1978; Derbaix, 1983; Hawes \& Lumpkin, 1986; Shimp \& Bearden, 1986; Akaah \& Korgaonkar, 1988; McCorkle, 1990; Jasper \& Ouelette, 1994):

- money-back or other guarantees - typically a refund if the customer is not satisfied or replacement if the product does not function properly;

- endorsement by an expert or a public figure - designed to create confidence;

- samples - a free miniature version of the product or a part of it is given to the customer;

- testing by an independent private institution - the fact that a product was tested and found suitable by a respected laboratory or other institution serves to relieve risks;

- testing by a government institution - similar to the above except that the testing institution is now part of or owned by government, for example the SABS or the CSIR;

- purchasing a well-known brand name - here the consumer relies on the known reputation of the brand to serve as a guide;

- information search - the process by which a consumer consults family, friends or colleagues to gather information to make an informed decision;

- brand loyalty - a consumer buys only a specific brand (trade mark) that has proved satisfactory in the past;

- purchasing the most expensive model - this reliever works on the price/quality relationship to the effect that the more expensive a product is, the higher its quality should be and 
- dealing only with big and reputable business firms - in the absence of other information, the consumer relies on organisations known for their dependable image.

The first six risk relievers above are initiated by the direct mail retailer, whilst the other four would be customer-initiated. All the above-mentioned risk relievers are included in this study as exogenous latent variables. It can be expected that an increase in or presence of risk relievers, would establish a positive relationship between the risk reliever and direct-order purchasing. In other words, the more effectively the risk relievers are used, the less the general risk perceptions of mail-order customers would be.

\section{SAMPLE AND DATA COLLECTION}

The population of the study was 57823 customers of a South African mail-order organisation who had bought more than twice from the organisation in the 18 months preceding the study. A sample of 2500 respondents were drawn from the population. The figure of 2500 respondents was based on an expected response rate of $20 \%$. A response rate of $20 \%$ would have resulted in the return of 500 questionnaires. This was based on a preferred ratio of 15 respondents per item as a norm which would have required 495 completed questionnaires to be returned to meet the desired cutoff point. It must, however, be pointed out that a 5 to 1 ratio is regarded as the minimum whilst a ratio of 10 to 1 is the more acceptable (Hair, Anderson, Tatham and Black, 1998: 98-9). The questionnaires were mailed to the respondents and a total of 422 questionnaires were returned, giving a response rate of $16,88 \%$. Because of the relatively low response rate, it was necessary to estimate for non-response bias. Because the data were captured in the same sequence in which the questionnaires were received, it was possible to use the method called time trends extrapolation as suggested by Armstrong and Overton (1977), to estimate for non-response bias. The assumption underlying this method is that the fourth quartile is the same as the nonrespondents. It was therefore necessary to determine whether the demographic characteristics of the fourth quartile differ from those of the first quartile. If no differences are found, quartiles one and four as well as the non-response are regarded as similar. The demographic characteristics of the first and fourth quartile were analysed to test for significant differences. A Chi-square goodness of fit test did not reveal any significant differences between the demographic variables of the first and the fourth quartiles. Table 1 contains the comparison of the first and fourth quartiles of the sample. 
Table 1 Comparison of first and fourth quartiles of the sample with regard to demographic characteristics by using a chi-square test

\begin{tabular}{|l|l|l|c|l|}
\hline \multicolumn{1}{|c|}{$\begin{array}{c}\text { Demographic } \\
\text { variable }\end{array}$} & $\mathbf{X}^{\mathbf{2}}$ & \multicolumn{1}{|c|}{ df } & $\begin{array}{c}\text { Critical } \\
\text { value } \\
(\mathbf{0 , 0 1} \text { level })\end{array}$ & \multicolumn{1}{c|}{ Conclusion } \\
\hline Household size & 2,62 & 4 & 13,28 & No significant difference \\
\hline Age of respondent & 3,81 & 4 & 13,28 & No significant difference \\
\hline Household income & 6,59 & 5 & 15,09 & No significant difference \\
\hline Cars in household & 6,25 & 4 & 13,28 & No significant difference \\
\hline $\begin{array}{l}\text { Time spent on occu- } \\
\text { pation/profession }\end{array}$ & 0,45 & 3 & 11,36 & No significant difference \\
\hline Education level & 2,32 & 4 & 13,28 & No significant difference \\
\hline Proximity of shops & 0,93 & 1 & 6,64 & No significant difference \\
\hline Physical disability & 0,34 & 1 & 6,64 & No significant difference \\
\hline Children & 1,99 & 1 & 6,64 & No significant difference \\
\hline Pre-school children & 1,26 & 2 & 9,21 & No significant difference \\
\hline $\begin{array}{l}\text { Time spent on } \\
\text { community/ welfare } \\
\text { activities }\end{array}$ & 3,04 & 4 & 13,28 & No significant difference \\
\hline Shift work & 2,64 & 1 & 6,64 & No significant difference \\
\hline $\begin{array}{l}\text { Time spent on } \\
\text { fitness/sport }\end{array}$ & 0,32 & 4 & 13,28 & No significant difference \\
\hline
\end{tabular}

Table 1 shows that when the first and fourth quartiles of the realised sample are compared in demographic terms, the two groups do not significantly differ from each other in any respect. As Armstrong and Overton (1977) argue that nonrespondents are similar to the respondents of the fourth quartile, it may therefore be concluded that non-response in this study has minimal impact on the representativeness of the sample.

The mail-catalogue organisation does not specialise in any particular merchandise, but offers a wide variety of products in 22 product categories, all of which may be characterised as low-involvement products. The lowinvolvement products referred to here have the usual characteristics of low price, little social concern and requiring very limited buying decision making. Typical products offered in the catalogue are cordless headphone sets for television, bathroom scales, sonic pest repellents and a range of apparatuses for exercising at home. 


\section{THE MEASURING INSTRUMENT}

A self-administered questionnaire was used as measuring instrument. Thirty (30) items were self-generated to represent the ten $(10)$ risk relievers available to respondents that purchase via mail-order catalogue. Each of the ten risk relievers was thus measured by three items. General risk perceptions were also measured by three items. All the items used were subjected to an experience survey as suggested by Churchill (1995: 152-3). Two professors of consumer behaviour and five other individuals were asked for their opinions in respect of the suitability of the items to measure the risk relievers studied. Each of the items had to be evaluated on a six-point Likert-type scale ranging from "Agree completely" to "Disagree completely".

\section{SCALE PURIFICATION}

The scale purification process consisted of three distinct phases: an assessment of the underlying dimensionality (and thus also discriminant validity) using exploratory factor analysis, an assessment of reliability by calculating Cronbach alpha coefficients and, finally, the theoretical model was subjected to empirical assessment by means of structural equation modelling.

\section{Dimensionality}

The first step was to assess whether the data do indeed contain 10 dimensions as suggested in the literature study. For this purpose, a Maximum Likelihood Exploratory Factor Analysis was conducted specifying a Direct Quartinum oblique rotation of the original factor matrix (Jennrich \& Sampson, 1966). The programme BMDP4M was used for the analysis. An oblique rotation was specified because the factors are correlated.

As several of the 30 items did not load a significant extent $(0,40)$ in several solutions or did not demonstrate sufficient discriminant validity by loading on more than one factor, these items were deleted as suggested by Churchill (1995). Several factor solutions had been considered and the most interpretable one to emerge was the eight-factor solution shown in Table 2 . The factor analysis results suggest that the proposed instrument demonstrates a considerable degree of discriminant validity. 
Table 2 Rotated Factor Loadings for the Eight Factor Solution

\begin{tabular}{|l|l|l|l|l|l|l|l|l|}
\hline & $\begin{array}{c}\text { Factor } \\
\mathbf{1}\end{array}$ & $\begin{array}{c}\text { Factor } \\
\mathbf{2}\end{array}$ & $\begin{array}{c}\text { Factor } \\
\mathbf{3}\end{array}$ & $\begin{array}{c}\text { Factor } \\
\mathbf{4}\end{array}$ & $\begin{array}{c}\text { Factor } \\
\mathbf{5}\end{array}$ & $\begin{array}{c}\text { Factor } \\
\mathbf{6}\end{array}$ & $\begin{array}{c}\text { Factor } \\
\mathbf{7}\end{array}$ & $\begin{array}{c}\text { Factor } \\
\mathbf{8}\end{array}$ \\
\hline ITEM & & & & & & & & \\
\hline Expen1 & $\mathbf{0 , 8 4 8}$ & & & & & & & \\
\hline Expen2 & $\mathbf{0 , 8 1 0}$ & & & & & & & \\
\hline Expen3 & 0,716 & & & & & & & \\
\hline Govt1 & & 0,817 & & & & & & \\
\hline Govt2 & & 0,757 & & & & & & \\
\hline Govt3 & & 0,713 & & & & & & \\
\hline Ptest1 & & & 0,777 & & & & & \\
\hline Ptest2 & & & 0,734 & & & & & \\
\hline Ptest3 & & & 0,730 & & & & & \\
\hline Samp1 & & & & 0,794 & & & & \\
\hline Samp2 & & & & 0,690 & & & & \\
\hline Samp3 & & & & 0,608 & & & & \\
\hline Advice1 & & & & & 0,870 & & & \\
\hline Advice2 & & & & & 0,536 & & & \\
\hline Advice3 & & & & & 0,499 & & & \\
\hline Brand1 & & & & & & 0,782 & & \\
\hline Brand2 & & & & & & 0,684 & & \\
\hline Expert1 & & & & & & & 0,737 & \\
\hline Expert2 & & & & & & & 0,675 & \\
\hline Expert3 & & & & & & & 0,447 & \\
\hline Source1 & & & & & & & & 0,893 \\
\hline Source2 & & & & & & & & 0,575 \\
\hline $\begin{array}{l}\text { Eigen- } \\
\text { values }\end{array}$ & 1,943 & 1,860 & 1,728 & 1,601 & 1,340 & 1,336 & 1,278 & 1,244 \\
\hline
\end{tabular}

According to Table 2 twenty-three of the original thirty items loaded to a significant extent on one of eight clearly identifiable factors. These factors were termed:
1) Expen
- purchasing of the most expensive model
2) Govt
- testing of a product by a government testing institution
3) Ptest
- testing of a product by a private testing institution
4) Samp
- availability of samples for inspection
5) Advice
- advice from family, friends and colleagues
6) Brand
- well-known brands
7) Expert
- endorsement by an expert 


\section{8) Source - reliable source}

\section{Reliability}

The remaining twenty three items were then, as suggested by Churchill (1995), subjected to a reliability analysis using the computer programme SAS PROC CORR (SAS Institute, 1988). Cronbach alpha values reported in Table 3 show that all the underlying dimensions of the construct "risk relievers in mail-order catalogue retailing" are measured by an instrument with sufficient reliability $(\alpha>0,7)$ and that the Cronbach alpha of the entire instrument is 0,88 . This figure exceeds the minimum of 0,7 suggested by Peterson (1994) and Nunnally (1978) and confirms the reliability of the instrument.

\section{Table 3 Internal Reliability Results}

\begin{tabular}{|l|c|}
\hline DIMENSIONS & $\alpha$ \\
\hline Most expensive product & 0,84 \\
\hline Government testing & 0,88 \\
\hline Private testing & 0,85 \\
\hline Samples & 0,84 \\
\hline Advice from family/friends/colleagues & 0,74 \\
\hline Brand loyalty & 0,81 \\
\hline Expert endorsement & 0,82 \\
\hline Reliable source & 0,81 \\
\hline Overall & 0,88 \\
\hline
\end{tabular}

\section{Path analysis}

The proposed instrument to measure the influence of risk relievers on general risk perception (Table 4) was then subjected to a path factor analysis (structural equation modeling). The results, set out in Table 5, suggest that the 8-factor model in Figure 1 represents a reasonable fit to the data (Hair, Anderson, Tatham and Black, 1998: 656). All the indices reported in Table 5 meet or exceed the minimum acceptable standards suggested by Hair, et al. (1998). The path analysis also provides some evidence of the construct validity of the proposed instrument (Tull \& Hawkins, 1993: 318). 
Table 4 Items to Measure the Influence of Risk Relievers on General Risk Perception

\section{Most expensive model}

EXPEN1 Ordering the most expensive model of a product reduces the risk of ordering by mail-order.

EXPEN2 It is safer to buy the most expensive model by mail-order catalogue of a product offered.

EXPEN3 A consumer reduces the risks related to mail-order by ordering the most expensive model of any product.

\section{Government testing}

GOVT1 If a mail-order catalogue contains the endorsement of a testing institution, like the SABS or CSIR, in respect of a product, then it makes the buying of that product safer.

GOVT2 Positive results and/or recommendation by a testing institution, such as the SABS or CSIR, in respect of a product offered by mailorder catalogue make it safer to buy by mail-order catalogue.

GOVT3 It is better to buy a product by mail-order catalogue if it has been tested and approved by a testing institution like the SABS of CSIR.

\section{Private testing}

PTEST1 Positive results and/or recommendations by a private testing institution in respect of a product offered by mail-order catalogue make it safer to buy by mail-order catalogue.

PTEST2 If a mail-order catalogue contains the endorsement of a product by a private institution, then it makes buying that product safer.

PTEST3 It is better to buy a product by mail-order catalogue if it has been tested and approved by a private testing institution.

Samples

SAMP1 A sample reduces the risk when buying by mail-order catalogue.

SAMP2 The availability of samples is likely to increase the buying of a product by mail-order catalogue.

SAMP3 A consumer is more likely to buy a product from a catalogue if a sample of the product is available before taking the buying decision. 


\section{Advice from family/friends/colleagues}

ADVICE1 Buying by mail-order catalogue is safer if one seeks advice from family, friends or colleagues before buying.

ADVICE2 It is important to obtain advice from other people who have bought by mail-order before buying oneself by mail-order catalogue.

ADVICE3 Advice from family, friends or colleagues makes buying products by mail-order catalogue less risky.

\section{Known brands}

BRAND1 A consumer can reduce risk when buying products by mail-order catalogue if he/she buys only products with well-known brand names.

BRAND2 When buying products by mail-order catalogue, it is safer to buy only products with brand names with which one has been satisfied in the past.

\section{Expert endorsement}

EXPERT 1 It is safer to buy a product by mail-order catalogue if it contains an endorsement by an expert.

EXPERT2 An endorsement by an expert in respect of a product in a mailorder catalogue reduces risk.

EXPERT3 It is more likely that a consumer will buy a product by mail-order catalogue if it contains a testimonial by an expert on the product.

\section{Reliable source}

SOURCE1 It is less risky when one deals with an established and well-known mail-order organisation.

SOURCE2 When a mail-order organisation is big and well known, then it makes transactions with such an organisation easier. 


\section{Figure 1 Empirical model : risk relievers}

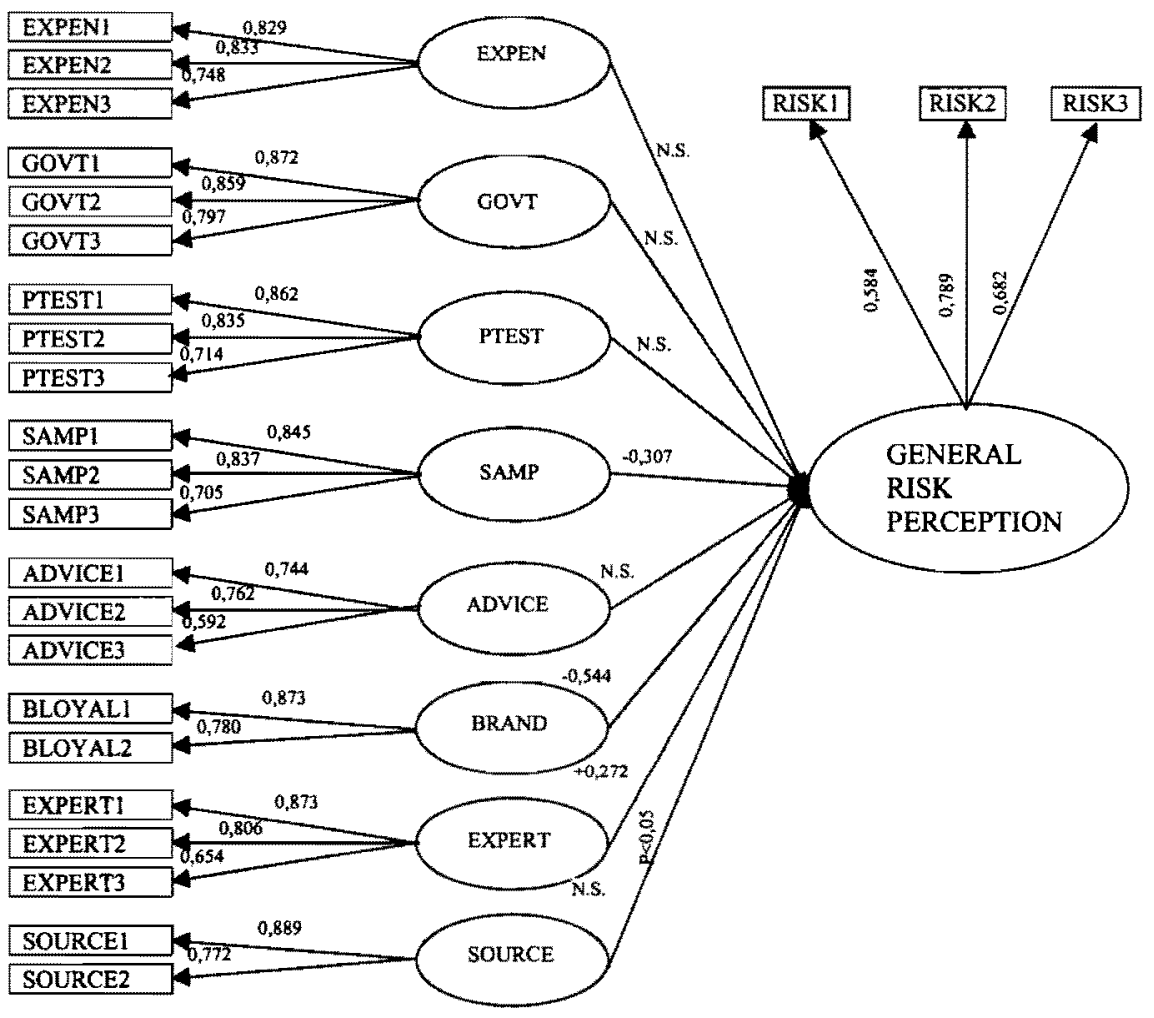

All path coefficients are significant at $p<0,01$ unless indicated otherwise 


\section{Table 5 Measures of Fit of the Model}

\begin{tabular}{|l|c|}
\hline RMSEA & 0,062 \\
\hline Modified AIC & 1,559 \\
\hline LISREL GFI & 0,890 \\
\hline LISREL Adjusted GFI & 0,850 \\
\hline Bentler-Bonnett Non-Formed Fit Index & 0,909 \\
\hline Tucker-Lewis Index & 0,909 \\
\hline RMR & 0,048 \\
\hline
\end{tabular}

\section{CONCLUSION AND EMPIRICAL RESULTS}

In conclusion it can be stated that the instrument developed has demonstrated sufficient reliability (Cronbach alpha values), discriminant validity (exploratory factor analysis) and construct validity (path analysis).

This study has produced evidence that only certain risk relievers, as identified in the literature survey, that are used in mail-order catalogue retailing, are also of importance to consumers that frequently purchase low-involvement products

Certain risk relievers did not impact on general risk perception and can therefore be regarded unsuitable in the case of low-involvement goods. For lowinvolvement goods providing samples and offering only well known brand names will reduce risk perceptions. Well-known brands are the most important risk reliever for low-involvement goods.

Endorsement by an expert actually increases risk perceptions. This finding is contrary to that reported in the literature. Possible reasons that might explain this are :

- respondents may not have a clear idea of what is meant by "an expert";

- the respondents could also have experienced source credibility, in the sense that they did not believe what the particular experts said and

- they could have also regarded the use of an expert for low-involvement goods as a "cover-up" of poor quality.

When one considers the respondents studied, it is not very surprising that some of the risk relievers did not feature. For instance, the respondents' familiarity with purchasing by mail-order catalogue offers some explanation for the little 
importance of guarantees. Because these consumers have purchased a number of times by mail-order, they are at ease with the arrangements offered by mailorder organisations. This is especially applicable to customers who have not yet had any negative encounters with a mail-order organisation, or those whose problems were addressed and solved in a manner acceptable to them.

\section{MANAGERIAL IMPLICATIONS}

As far as the managerial implications of the above findings are concerned, managers of mail-order catalogues could consider the following :

- direct marketers should determine which brands of the low-involvement products are the most important to customers. If research can identify these brands, mail-order organisations would be more effective in their marketing efforts if they only focus on such brands;

- the use of samples could be extended, especially with regard to the brands referred to above. The opportunity to know a product before purchasing it, has a major risk reduction propensity. It is however difficult, even impossible, to provide samples of certain products and

- resources allocated to risk relievers, other than those found to be effective in this study, should be scaled down. This is particularly relevant to the cost incurred in respect of expert endorsements.

What is, however, important from the perspective of mail-order catalogue managers, is that a variety of risk relievers need to be offered to ensure that different kinds of perceived risk are properly addressed. The findings indicate that mail-order catalogue organisations must endeavour to make both of the risk relievers mentioned, namely samples and well-known brand names, available as far as possible.

This research has provided additional insight into the risk relievers that are important to low-involvement products. Future research should aim to determine the relationship between particular demographic variables and the risk relievers identified in this study. Such information can be valuable in the design of marketing offers. 


\section{REFERENCES}

1 AKAAH, I.P. \& KORGAONKAR, P.K. (1988) "A Conjoint Investigation of the Relative Importance of Risk Relievers in Direct Marketing", Journal of Advertising Research, August/September: 38-44.

2 ARMSTRONG, J.C. \& OVERTON, T.S. (1977) "Estimating Nonresponse Bias in Mail Surveys", Journal of Marketing Research, 14, August: $396-402$.

3 CHURCHILL, G.A. (Jr.) (1995) Marketing Research: Methodological Foundations, 6th ed., Dryden Press, Fort Worth..

4 DARIAN, J.C. (1987) "In-Home Shopping: Are There Consumer Segments?", Journal of Retailing, 63, Summer: 163-86.

5 DERBAIX, C. (1983) "Perceived Risk and Risk Relievers: An Empirical Investigation", Journal of Economic Psychology, 3(1): 19-38.

6 FESTERVAND, T.A., SNYDER, D.R. and TSALIKIS, J.D. (1986) "Influence of Catalog vs. Store Shopping and Prior Satisfaction on Perceived Risk", Journal of the Academy of Marketing Science, 14, Winter: 28-36.

7 HAIR, J.F. (Jr.), ANDERSON, R.E., TATHAM, R.L. and BLACK W.C. (1998) Multivariate Data Analysis, 5th ed., Prentice Hall, Upper Saddle River.

8 HAWES, J.M. \& LUMPKIN, J.R. (1986) "Perceived Risk and the Selection of a Retail Patronage Mode", Journal of the Academy of Marketing Science, 14, Winter: 37-42.

9 HOOVER, R.J., GREEN, R.T. and SAEGERT, J. (1978) "A CrossNational Study of Perceived Risk", Journal of Marketing, 42, July: 102-8.

10 JASPER, C.R. \& OUELETTE, S.J. (1994) "Consumers' Perception of Risk and the Purchase of Apparel from Catalogs", Journal of Direct Marketing, 8, Spring: 23-6.

11 JENNRICH, R.I. \& SAMPSON, P.F. (1966) Rotation for Sample Loadings, Psychometrika, 31: 313-23.

12 McCORKLE, D.E. (1990) "The Role of Perceived Risk in Mail Order Catalog Shopping", Journal of Direct Marketing, 4, Autumn: 26-35.

13 McNAIR, M.P. \& MAY, E.G. (1978) "The Next Revolution of the Retailing Wheel", Harvard Business Review, 56, September-October: 81-91.

14 MITCHELL, V-W. \& MCGOLDRICK, P.J. (1996) "Consumers' RiskReduction Strategies: a Review and Synthesis", The International Review of Retail, Distribution and Consumer Research, 6(1): 1-33.

15 NUNNALly, J. (1978) Psychometric Theory, 2nd ed., McGraw-Hill, New York.

16 PETERSON, R.A. (1994) "A Meta-Analysis of Cronbach's Coefficient Alpha", Journal of Consumer Research, 21(3): 381-91. 
17 RAPP, S. \& COLLINS, T. (1990) The Great Marketing Turnaround. Englewood Cliffs : Prentice-Hall.

18 ROSELIUS, T. (1971) "Consumer Rankings of Risk Reduction Methods", Journal of Marketing, 35, January: 56-61.

19 ROSENBERG, L.J. \& HIRSCHMAN, E.C. (1980) "Retailing Without Stores", Harvard Business Review, 58, July-August: 103-12.

20 SAS INSTITUTE INC. (1988) SAS Procedures (Release 6.03 Edition). Cary, N.C.: Author.

21 SHIMP, T.A. \& BEARDEN, W.O. (1982) "Warranty and Other Extrinsic Cue Effects on Consumers' Risk Perceptions", Journal of Consumer Research, 9, June: 38-46.

22 SPENCE, H.E., ENGEL, J.F. and BLACKWELL, R.D. (1970) "Perceived Risk in Mail-Order and Retail Store Buying", Journal of Marketing Research, 7, August: 364-9.

23 TULL, D.S. \& HAWKINS, D.I. (1993) Marketing Research: Measurement \& Method, 6th ed, Macmillan Publishing, New York.

24 VAN DEN POEL, D. \& LEUNIS, J. (1996) "Perceived Risk and Risk Reduction Strategies in Mail-Order Versus Retail Store Buying", The International Review of Retail, Distribution and Consumer Research, 6(4): 351-71. 